\title{
Molecular genetic biotechnologies - the way to the welfare of the people and increasing of agriculture profitability
}

\author{
A. I. Potopalsky, O. I. Bolsunova, L. A. Zaika \\ Institute of Molecular Biology and Genetics, NAS of Ukraine \\ 150, Akademika Zabolotnogo Str., Kyiv, Ukraine, 03680 \\ Institute of Health Promotion and Rebirth of People of Ukraine \\ 150, Akademika Zabolotnogo Str., Kyiv, Ukraine, 03680 \\ potopalsky@imbg.org.ua
}

\begin{abstract}
We have designed and offered a comprehensive approach to solving several problems in modern agriculture and human health. It is based on the original use of biotechnology. The mechanisms of alkylation of amines, nucleic acids and their derivatives by etylenimin components have been investigated. Alkylation products were purified and characterized, their biological activity, studied in various systems, was identified as well as their antitumor, antiviral and immunomodulatory effects. Based on the development of original methods of natural substances modification and the use of obtained products for the regulation of molecular biological processes a new scientific direction has been created. This article presents the results of over 50-years-old research on development of original biotechnological methods.
\end{abstract}

Keywords: modification, natural substances, amitozyn, izatizon, new varieties, biotechnologies.

Climate change creates the most dangerous threat of our time because of careless use of earth resources, destroying the ecosystem and leads to the loss of biodiversity in the world. The task of careful and most responsible regulatory impact upon both healthy and sick organisms of living beings is no longer the concern just of scientists. By thousands years of history humanity has certainly proved to have inexhaustible self-regulating abilities and reserves of wild Nature. For over fifty years we have been studying the problems of regulation of biological processes under health and disease conditions, especially under so-called stress conditions and induced fatal diseases.

The technology has been elaborated to struggle against widespread viral diseases with drug izatizon, which has a broad spectrum of antiviral activity, including DNA-and RNA-containing viruses, viral and microbial associations. Unique anticancer drug amitozyin with the immunomodulating and antiviral action, that

(C) Institute of Molecular Biology and Genetics, NAS of Ukraine, 2013 has been created, is perhaps the only preparation in the world that does not cause side effects at undoubted anticancer activity. Based on DNA and RNA preparations, their components and analogues, the biotechnology has been developed for regulation of biological process and accelerated production of new forms, varieties and species of agricultural and medicinal plants resistant to extreme environmental factors: drought, frost, salinity and nitrogen-depleted soils.

The objects of our study are natural substances, life products of microorganisms, plants, fungi, insects and animals. These are alkaloids, biogenic amines, aminoacids, proteins, carriers of hereditary information - nucleic acids and their precursors.

Due to our new method of purposeful modifying natural molecules by alkylation, it is possible to enhance the resistance of living beings to unfavorable environmental factors, to prevent mass viral and bacterial diseases, including tumour growth, immunoagressive and immune deficiency conditions. Of special note is a pos- 


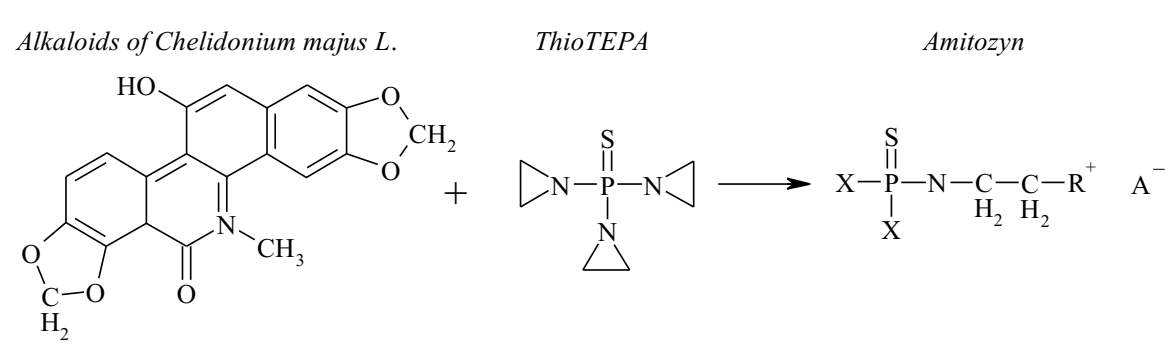

Scheme of amitozyn synthesis, the
first representative of a new scien-
tific direction (A. I. Potopalsky). X=
$=-\mathrm{N}^{-}-\mathrm{CH}_{2}-\mathrm{CH}_{2}-\mathrm{R}^{+} ; \mathrm{R}=$ Alkaloids
of Chelidonium majus sible regulatory effect of such substances upon inherited disorders and radioactive poisoning.

The first substance of this type, able together with its analogues to stop this destructive actions, was antitumour, antiviral and antimicrobial, immune-regulating preparation amitozyn. It was obtained by us in 1959 through alkylation of the sum of alkaloids extracted from a well-known plant - greater celandine (Chelidonium majus L.) by antitumour preparation thiophosphoamide (ThioTEPA) (A. I. Potopalsky, 1961)[1-4]. The figure represents the scheme of amitozyn synthesis.

For over fifty years this preparation was used independently and in many complexes for the treatment of malignant and benign tumors, immune aggressive and viral formations. The clinical test of amitozyn, conducted in 1967-1968 in the former USSR, proved its high medicinal properties in the treatment of tumors of larynx, cervix uteri, prostate, ovaries, pancreas and mammary gland, urinary bladder, melanoblastoma etc., as well as of non-malignant tumours (polyps, papillomas, adenomas, fibromiomas). These data were supported by recent clinical studies of amitozyn, conducted in 1998-2001 according to the Ministry of Health of Ukraine on the basis of the Oncology and Medical Radiology Research Institute of the Academy of Medical Sciences of Ukraine. In collaboration with $\mathrm{O}$. S. Abrahamovich, a doctor from Lviv, amitozyn was proved to possess a high medicinal activity in treatment of viral infectious polyarticular rheumatoid arthritis. Amitozyn did not inhibit hemopoiesis and immunity of patients but even improved them, promoting the resistance of an organism. It is the first preparation of a new class of phytolytic substances - the products of alkylation of amines with various actions.

The approach for obtaining a large group of antitumor products of alkylation of isoquinoline alkaloids of triethyphoms, elaborated in collaboration with M. Turkevich, M. Oliyovskaya, V. Ya. Novitsky in 1969 was patented in 16 countries.
The toxicity of amitozyn is several times lower than that of some of its components - the sum of greater celandine alkaloids and thiophosphamide. High antitumor activity of amitozyn in the experiment was proved in the clinical trial on patients with fatal forms of malignant tumors (Table). Complete clinical recovery was observed in 17-18\% cases, whereas reduction of tumors and life prolongation - in $75 \%$ cases. The complications common to most antitumor preparations (hemopoiesis inhibition, dyspeptic effects, hair loss and others) were not observed. At the same time the characteristics of immunogram were normalized and specific cancerous antigens disappeared or decreased considerably. In this case most of cancer cells die through apoptosis - the natural aging process [5]. An inherited resistance in a new generation of the rats cured from Heren cancer was determined.

Another unique preparation «Izatizon» was developed as an effective immune modulator in collaboration with L. V. Lozyuk in 1973. It is successfully used for prevention and treatment of viral and bacterial-viral infections and tumours in veterinary, medicine, crop production] $[6,7]$.

L. A. Zaika and O. I. Bolsunova, the members of the laboratory, opened and interpreted immunomodulatory properties of izatizon. In close cooperation with D. M. Hovorun it has been found, in particular, that a wide range of izatizon biological activity is based on conformationally labile structure of the molecule of metysazon, the main active component of the drug, and depends on the properties of the solvent and microenvironment $[8,9]$.

Izatizon is a new generation drug that combines the antiviral activity and immunotropic action revealing also anticancer properties, especially in case of melanoblastoma. It is experimentally proved that izatizon affects both viruses and cellular mechanisms of the immune system. In model systems of herpes virus and adenovi- 
Overall result of amitozyn treatment of patients with head and neck malignant tumors (survival, \%)

\begin{tabular}{c|c|c}
\hline \multirow{2}{*}{ Survival } & \multicolumn{2}{|c}{ Patients group } \\
\cline { 2 - 3 } & Control group & Main group \\
\hline 2-year & $52.2 \pm 4.2$ & $91.9 \pm 3.5^{*}$ \\
3-year & $47.0 \pm 5.0$ & $70.1 \pm 5.0^{*}$ \\
5-year & $40.2 \pm 5.2$ & $66.1 \pm 6.6^{*}$ \\
\hline
\end{tabular}

N o t e. $* \mathrm{p}<0,05$

rus we detected that izatizon has an ability to stimulate the reparative DNA synthesis. [10]

We discovered the drug ability to inhibit the thymidine kinase activity of the herpes virus and adenovirus that results in inhibition of virus at the early stages of infection. We found the izatizon curative effect upon herpes virus and adenoviral infections and its availability at AIDS, tuberculosis and hepatitis C. Our data show convincingly a significance of this drug, especially nowadays, when all the continents of the earth witness a dramatic increase in the number of viral and immune aggressive diseases that were considered disappeared as well as appearance of new ones, among which the viral diseases make an essential part. Izatizon is active against DNA-and RNA-containing viruses, it also has pronounced immunomodulatory properties [11].

Moreover, izatizon is an activator of nonspecific resistance factors via its stimulating effect on the metabolic and phagocytic functions of macrophages, and the influence on natural killer cells activity and synthesis of lysozyme

Altogether over 60 new preparations with antitumour, antiviral and immune modulating action are patented, 15 original phyto-teas are elaborated on the basis of celandine, over 20 new forms, varieties and types of medical and agricultural plants are created, 6 of which are approved by State Inspection of Plant Varieties of Ukraine and recommended for a wide use as new varieties with an elevated yield and a high content of active substances. Eleven of the indicated phyto-teas with celandine and dozens of other plants, are produced by Zhitomir closed company «Medherbs under the brand of «Doctor A. I. Potopalsky» (certification trade mark N 109425): Angiotumorosan, Artrourosan, Ghastrosan, Dermosan, Enterosan, Imunosan, Pneumosan, Tumorosan, Urosan, Kholeurosan, Cardiosan. They recover an organism, treat benign and malignant tumours, polyarthritis, multiple sclerosis. The plants of own selection: Purple echinacea «Beauty of Polissya», «Blueness of Polissya» vipers bugloss, molecular hybrid of pumpkin and watermelon «Zdorovyaga» kavbuz - are used for production of such recommended food supplements as «Spokiy» (Calmness), «Badioryst» (Vivacity), «Bud'mo zdorovi» (Be healthy), «Kavbuzol», «Kavbuzosorb», kavbusorb anthelmintic, kavbusorb re juvenating.

A number of modern biotechnologies were elaborated: targeted improvement of hereditary information of biological objects; environmental cleansing by application of the plants able to assimilate atmospheric nitrogen instead of expensive fertilizers; obtaining good crop capacity of plants on highly saline soils; increase of productivity of beneficial insects, fishes, birds, animals; a method to control agrobacterial cancer of plants [12]. In 1979 on the territory of 40 hectares of noncropland in the village Khodaky of Korostensky district in Zhytomyr region, the dendropark «Peremoga» is organized with the goal to found a selective seed base and as recreation area.

Based on nucleic acids and their components, some stimulants of plant growth have been recently developed. The methods of native and modified nucleic acids application for modification of the genetic apparatus of plants are under development. [13]

Genetic effects of alkylated DNA were determined and some new varieties and forms of rye, millet and tomatoes with valuable qualities have been obtained. A special sort of fodder lupine with increased protein content «Industrial» and pumpkin Kavbuz «Zdorovyaha», rye «Drevlyanske», tomato «Ukrainian», Echinacea «Woodland Beauty» are registered in the State Register of plants of Ukraine and protected by copyright certificates of Ukraine. A pilot study on modified products of alkaloids and their analogues and derivatives with a wide range of biological activity is carried out. These results are used to improve human health and the environment. A technology of obtaining new forms of plants with desired properties is created using the approach of structural modification of molecules-carriers of hereditary information (DNA and RNA).

A wide application of these achievements has a considerable economic and social effect, in particular, for environmental recovery, obtaining intense yield on 
highly saline and nitrogen-depleted soils, as well as during the hydroponic growing with the use of seawater without its desaltation. The created hybrids impress even professional selectionists: kvagista (molecular hybrid of haricot and cabbage) is a unique edible and feed culture up to three meters high with high protein content; kavbuz (molecular hybrid of pumpkin and watermelon) - the largest in the world berry of more than $60 \mathrm{~kg}$ of weight, it promotes removal of heavy metals and radionuclides from the organism; Kiziris (molecular hybrid of cornel and barberry); Alycos (molecular hybrid of cherry-plum and apricot). The high viral and immunomodulating effect of amitozyn and izatizon was proved in 1992-1994 according to the program of the National AIDS Committee established by the President of Ukraine. However, these unique results have not been implemented yet.

We offer the completed scientific elaborations, complex methods of spiritual and molecular-genetic recovery of human and environment to concerned teams for collaborative implementation:

- Having no analogues in world practice antiviral, antimicrobial and antitumour preparations «Izatizon», «Izatitoniy», «Amitozyn», «Amitozynoberamid» with a high economic effect when using in medicinal care, veterinary medicine, crop production;

- New varieties of cereals with high productivity on nitrogen-depleted and highly saline soils (wheat, rye, oat, millet, barley, corn, sorghum, rice), resistant to drought, bacterial and mycotic infections;

- New types of pumpkin for introduction to farming (kavbuz, kavbudek, enriched in sugars, fructose in particular, carotene and oil);

- New varieties and forms of medical plants, which have immunomodulating, bactericidal and anti-inflammatory effects (Echinacea, viper's bugloss, elecampane, thermopsis, phytolacca);

- Salt-resistant and drought-resistant forms of plants, tomatoes of «Ukrainian Salt Tolerant» variety in particular;

- Technology of cereals and vegetable cultures seed treatment, and treatment of mushrooms, which increases the productivity by $20-40 \%$;

- Technology of beneficial insects productivity increase in beekeeping, production of oakworm and silkworm, etc. The proposed biopreparations are not harm- ful and provide the increase in beneficial insects productivity by $1.5-2$ times;

- Technology of creation of new forms of plants with modified properties (creation of frost-, salt-, drought- resistant forms, transformation of winter forms of crops to spring crops);

- Technology of fishery and sea-farming productivity increase by $20-40 \%$;

- Technology of diagnostics, prevention and treatment of bacterial cancer of plants (fruit cultures, grape, vegetable cultures) by using original, ecologically harmless preparations.

In 2005 International scientific-practical forum «Bases of molecular-genetic health improvement of both human and environment» took place in the Institute of Molecular Biology and Genetics, it was dedicated to a new scientific direction of molecular structure modification of biologically active substances, that was awarded the top assessment both at home and abroad. Materials of this forum are presented on the web-site http://www. potopalsky.kiev.ua/ua/forum.html. The number of visitors from more than 50 countries is still growing.

\section{А. І. Потопальський, О. І. Болсунова, Л. А. Заӥка}

Молекулярно-генетичні біотехнології - шлях до добробуту населення і підвищення прибутків сільського господарсва

\section{Резюме}

Нами створено $і$ запропоновано комплексний підхід до вирішення багатьох проблем сучасності в галузі сільського господарства $i$ здоров 'я людини. Він базується на застосуванні оригінальних біотехнологій. Досліджуються механізми алкілування амінів, нуклеінових кислот та їхніх компонентів похідними етиленімінів. Продукти алкілування очищено і охарактеризовано, виявлено їхню біологічну активність, досліджувану в різних системах, а також їхні протипухлинні, противірусні та імуномодулюючі ефекти. На основі розробки оригінальних методів модифікації природних речовин та використання одержаних продуктів для регуляиї молекулярно-біологічних процесів створено новий науковий напрямок. Викладено результати понад 50-річних науково-практичних досліджень зазначених сполук.

Ключові слова: модифікачія, природні субстаниї, амітозин, ізатиізон, нові види, біотехнології.

\section{А. И. Потопальский, О. И. Болсунова, Л. А. Заика}

Молекулярно-генетические биотехнологии - путь к благосостоянию населения и повышению прибыльности сельского хозяйства

Резюме

Нами создан и предложен комплексный подход кремению многих проблем современности в области сельского хозяйства и здоро- 
вья человека. Он основан на применении оригинальных биотехнологий. Исследуются механизмы алкилирования аминов, нуклеиновых кислот и их компонентов производными этилениминов. Продукты алкилирования очищень и охарактеризованы, выявлена их биологическая активность, исследуемая в различных системах, а также их противоопухолевые, противовирусные и иммуномодулирующие эффекты. На основе разработки оригинальных методов модификаџии природных веществ и применения полученных продуктов для регуляции молекулярно-биологических процессов создано новое научное направление. Изложены результаты более чем 50-летних научно-практических исследования указанных соединений.

Ключевые слова: модификация, природные субстанции, амитозин, изатизон, новые виды, биотехнологии.

\section{REFERENCES}

1. Potopalsky A. I., Petlychnaya L. I., Yvasyvka S. V. Modification of berberin alkaloids.-Kyiv: Naukova Dumka, 1980.-109 p.

2. Potopalsky A. I. Amitozyn action on experimental malignant tumors in rats // Oncology Questions: Proc. of Scientific Medical Students Societies of Medical Intitutions of RSFSR (Moscow, 9-12 April 1963).-Moscow, 1963.-P.

3. Potopalsky A. I. Some data about the treatment of malignant tumors in the experiment // XXXI Conf. of Student Scientific Society (14-15 December 1961 Stanislav's State Medical Institute).Stanislav, 1961.-P. 36-37.

4. Potopalsky A. I. Celandine preparations in biology and medicine.Kyiv: Naukova Dumka, 1992.-200 p.

5. Herman B., Gudrun A., Potopalsky A. I., Chroboczek J., Tcherniuk S. O. Amitozyn impairs chromosome segregation and indu- ces apoptosis via mitotic checkpoint activation // PLoS One.2013.-8, N 3.-e57461.

6. Potopalsky A. I., Lozyuk L. V., Mirolyubova A. N., Bessarabov $B$. F. The antiviral, anticancer and antileukemia drug izatizon.Kyiv: Naukova Dumka, 1991.-191 p.

7. Lozyuk L. V., Potopalsky A. I., Lozyuk R. M. Medical treatment and prevention of viral diseases.-Lviv: Norma, 2003.-208 p.

8. Potyahaylo A. L., Bolsunova O. I., Zayika L. A., Potopal'sky A. I., Hovorun D. M. Conformational analysis of metysazon molecule: semi-empirical quantum chemical data // Biopolym. Cell.2003.-19, N 3.-P. 292-294

9. Potyahaylo A. L., Bolsunova O. I., Zayika L. A., Potopalsky A. I. Prototropic tautomerism, proton acceptor and proton donor properties of isatin: quantum chemical calculation data // Biopolym. Cell.-2003.-19, N 2.-P. 202-204.

10. Zaika L. A., Bolsunova O. I., Patskovsky Yu. V., Rubashevsky E. L., Diadiun S. T., Ribalco S. L., Potopalsky A. I. The antiviral drug izatizon possesses no mutagenic action and stimulates proliferation of cells of immune system // Biopolym. Cell.-1995.11, N 6.-P. 89-95.

11. Zaïka L. A., Bolsunova O. I., Potopalsky A. I. Antiviral, anticancer and immunomodulatory properties of IZATIZON therapeutic drug.-Kyiv: Kolobig, 2010.-212 p.

12. Potopalsky A. I., Jurkiewicz L. N. Third Millennium - new plants for health, wellbeing, beauty and longevity.-Kyiv: Kolobig, 2005.-168 p.

13. Katsan V. A., Potopalsky A. I. Features of action of exogenous DNA preparations in obtaining some new forms of tobacco.Kyiv: Kolobig, 2007.-176 p.

Received 01.04.13 